\author{
Review Article \\ www.ijrap.net
}

\title{
A REVIEW ON PHYSIOLOGY OF PURISHAVEGA (DEFECATION REFLEX)
}

Neha Dattatraya Gadgil ${ }^{1 *}$, Kalpana Dilip Sathe ${ }^{2}$, Vinita Deshmukh ${ }^{3}$, Akshar Kulkarni ${ }^{4}$, Abhijit H. Joshi ${ }^{5}$

${ }^{1} \mathrm{Ph} . \mathrm{D}$ Scholar, Tilak Maharashtra Vidyapeeth, Pune, India \& Assistant professor, Department of Kriya Sharira,

SDM college of Ayurveda \& Hospital, Hassan, Karnataka, India

${ }^{2} \mathrm{Ph} . \mathrm{D}$ Guide, Professor and Head of the Department, Department of Kriya Sharira, Sumatibhai Shah Ayurveda

Mahavidyala, Hadapsar, Pune, India

${ }^{3}$ Professor and Head of the Department, Department of Sanskrit Samhita Siddhant, BSDT's Ayurveda Mahavidyalaya, Wagholi, Pune, India

${ }^{4}$ Assistant Professor, Department of Kriya Sharira, SDM college of Ayurveda \& Hospital, Hassan, Karnataka, India

${ }^{5} \mathrm{Head}$ of the department, Department of Ayurveda, Tilak Maharashtra Vidyapeeth, Pune, India

Received on: 17/11/16 Revised on: 19/12/16 Accepted on: 03/01/17

\begin{abstract}
*Corresponding author
E-mail:vdnehak@gmail.com
\end{abstract}

DOI: $10.7897 / 2277-4343.0811$

\section{ABSTRACT}

Vega is distinctive concept of Ayurveda which deals with natural urges of body like hunger, thirst, urination, defecation etc. In Ayurveda, process of Vega is not directly mentioned. With the help of supplementary references from compendia it can be fashioned. Purisha (feces) is the product of digestion. It must be eliminated out of body. The urge for excretion of Purisha is called Purishavega (defecation reflex). Initiation from Atma (soul), Indriya (senses), and Manas (mind) in conjunction with Sparshanendriya (skin) and Vata Dosha Process of Purishavega takes place.

Keywords: Vega, Purishavega, Vata, Dosha, Sparshanendriya, defecation reflex

\section{INTRODUCTION}

Our body gives certain indications for its needs in the form of Vega (urge) like hunger, thirst, urination, defecation and regarding psychological factors like anger, desire etc. out of these Shariraka (related to body) Vega are considered as Adharaniya i.e. which are not supposed to be hold. Manas (related to mind) Vega are considered as Dharaniya i.e. which are supposed to be hold. Purishavega (defecation) comes under Adharaniya Vega.

Vega reflects body's need. However, the physiology behind these Vega is not clearly depicted in Ayurvedic literature. So, to enlighten the process of Vega especially Purishavega, this attempt is made.

Vega is derived from Vij Dhatu. It means Impulse, Impetus, Evacuation of feces, and Paroxysm of disease. Vega is natural body urge to pass Mala (feces), Mutra (urine) etc ${ }^{1}$.

- Vega is Gativishesha, or it is a part of Gati (speed).

- Vega is described in terms of Disha (direction) and Kala (time).

- Vega is related to Dravya (substance) which has its own or specific Gati or Vega.

Every Sharira Kriya (physiologic process) requires Antakarana Pravrutti first i.e. Pravartana (involvement) of Atma and Mana. Vega are classically classified in two groups - Dharaniya and Adharaniya Vega. Dharaniya Vega are which are supposed to be hold or avoided ${ }^{2}$. Adharaniyavega are those which are not supposed to be hold. These include urges of Adhovata (flatulence), Urdhvavata (belching), Purisha (feces), Mutra (urine), Kshavathu (sneezing), Trushna (thirst), Kshudha (hunger), Nidra (sleep), Kasa (cough), Shramashvasa (increased respiratory rate due to heavy work), Jrumbha (yawning), Ashru (tears), Chardi (vomiting), Shukra (semen) ${ }^{3}$. If these are hold, they cause harm.

Meaning of Purisha is Malinabhava (dirty thing) or Tyajyatva (waste) i.e it should be thrown out of body. Purisha and Mutra are Mala of Anna (food). After Sara-Kitta Vibhajana (segregation of useful and waste part), Sara Bhaga (useful part) becomes Rasa (entity of body) and Kitta Bhaga (waste part) becomes Mala ${ }^{4}$. Sharira Poshana (nourishment of body) takes place from Sara Bhaga. Kitta Bhaga does Poshana (nourishment) of Sweda (sweat), Mutra (urine), Purisha (feces), Vata, Pitta, Kapha (Dosha in body) and other Dhatu Mala (waste products from Dhatu) ${ }^{5}$.

Purisha is a result of Anna pachana Kriya (digestion). It is formed in Pakwashaya (large intestine) at third stage of Avasthapaka (process of digestion) ${ }^{6}$. At this stage, Agni does Shoshana (makes dry) of Anna (food) and 'Paripindita' (formed or solid state) form of Purishais achieved. Katubhava gives rise to Ahara-Mala-Rupa-Vata (flatulence). Visarjana (excretion) of Purisha and Aharamala Vata from Guda (anal canal) is under control of Apana Vayu (a subtype of Vata Dosha) ${ }^{7}$. 
This process can be summarized as follows.

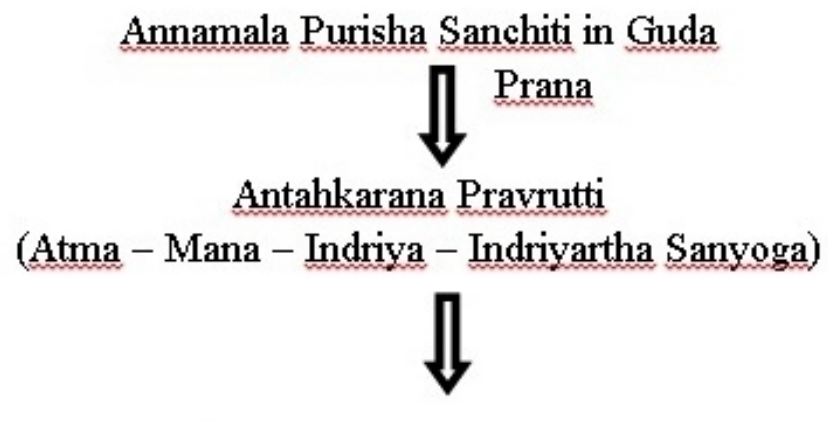

Perception received by Sparshanendriva

$\downarrow$

Vid-dvesha in Sparshanabuddhi

$\prod$ Vyana

Stimulus to Apana Kshetra

$\downarrow \frac{\text { Apana }}{33}$

Purishavega - Malavisarjana

\section{DISCUSSION}

Role of Prana (a subtype of Vata Dosha)

The action of Vid - Visarjana (defecation) is initiated and control by Prana (a subtype of Vata Dosha) as Indriyadharana (control of senses) is function of Prana ${ }^{8}$. Sthana (place) of Prana and Indriya is Shira (head) ${ }^{9}$. Shira (head) is considered as Uttamanga (higher functional part) ${ }^{10}$. In case of Shirobhihata (head injury), Vega Nirmana Prakriya (formation of urges) is not proper. Cheshtanasha (hampered movements) is described in Shirobhihata Lakshanani (symptoms) ${ }^{11}$.

Role of Sparshanendriya (Sense of touch) and Chetas (mind) Utsarga (elimination) of Purishaby Karmendriya (organ to perform action) Guda (anal canal) does not take place without Indriyajnana (sensation). Sparshanendriya (sense of touch) is covers everything. It is in Samavaya Sambandha (relation) with Chetas (mind). So Chetas is also everywhere in body ${ }^{12}$. The Lakshana (characteristic) of Panchamahabhuta as well as their opposite Lakshana are Sparshanendriya Gamya (recognized by sense of touch) ${ }^{13}$. Sukha-Dukha Vedana Pravartana (knowledge of all good and bad feelings) is done by Sparsha (touch) ${ }^{14}$. When fecal matter is collected in rectum, it is percept by Sparshanendriya (sense of touch) by Pratyaksha Jnana (direct contact) in following steps ${ }^{15}$.

- Sanyogasannikarsha - Sannikarsha of Vid-Dravya with Mansadhara Tvacha (contact of fecal matter with internal lining of rectal and anal canal).

- Sanyuktasamavaya Sannikarsha - Sparsha of Vid-dravya and its Tyajyatva Jnana to Mamsadhara Tvacha (awareness regarding uselessness of fecal matter).
- Sanyukta Samaveta Samavaya Sannikarsha - Dukhadayaka - Sparshajnana and its Unupayuktata is perceived by Mamsadhara Tvacha (Guna-Karma Sannikarsha of Dravya) (feeling of throwing out of useless part)

- Vid-dvesha in Sparshanabuddhi after Vishaya - Indriya Mana - Atma Sannikarsha (urge of defecation).

Thus Sparshanendriya (sense of touch) plays important role in Purishavega (defecation).

\section{Role of Vata}

Payu (anal canal) Karmendriya (organ to perform action) is stimulated by Sparshanabuddhi (power of analyzing touch) via Vyanavayu (a subtype of Vata Dosha) to perform Vid-Vibhaga (detachment of fecal matter). Vyana is responsible for all types of Gati (movements) in Sharira (body) ${ }^{16}$.

KarmendriyaPayu, with the help of Sthanika (local) Vayu Apana (a subtype of VataDosha) brings about the action of Vega Vid-Visarjana (defecation) ${ }^{7}$.

\section{CONCLUSION}

Vega is physiological process. Involvement of Atma (soul), Jnanendriya (senses) and Manas (mind) is required for initiation of Vega Process. In case of Purishavega, Sparshanendriya (sense of touch) plays important role. Association of Vata Dosha, Karmendriya (organ to perform action) is obligatory for execution of Vega process. 


\section{REFERENCES}

1. Acharya J. T., Charaka Samhita, Sutrasthana, Chapter 7, Verse 1-4, commentary of Chakrapani, $1^{\text {st }}$ ed, Delhi; Chaukhambha orientalia, 2004; p.49

2. Kunte A. M., Ashtanga Hrudayam, Sutrashana, Chapter 4, Verse 24, reprint 2000, Varanasi; Krushnadas academy, 2000; p.57

3. Kunte A. M., Ashtanga Hrudayam, Sutrashana, Chapter 4, Verse 1, reprint 2000, Varanasi; Krushnadas academy, 2000; p. 52

4. Acharya J. T., Charaka Samhita, Chikitsasthana, Chapter 15, Verse 18, $1^{\text {st }}$ ed, Delhi; Chaukhambha orientalia, 2004; p.515

5. Acharya J. T., Charaka Samhita, Sutrasthana, Chapter 28,

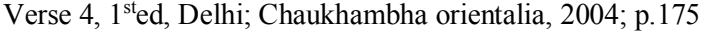

6. Acharya J. T, Charaka Samhita, Chikitsasthana, Chapter 15, Verse 11, $1^{\text {st }}$ ed, Delhi; Chaukhambha orientalia, 2004; p.512

7. Kunte A. M., Ashtanga Hrudayam, Sutrashana, Chapter 12, Verse 9, reprint 2000, Varanasi; Krushnadas academy, 2000;p. 193

8. Kunte A. M., Ashtanga Hrudayam, Sutrashana, Chapter 12, Verse 4, reprint 2000, Varanasi; Krushnadas academy, 2000; p.193

9. Acharya J. T., Charaka Samhita, Sutrasthana, Chapter 17, Verse 12, $1^{\text {st }}$ d, Delhi; Chaukhambha orientalia, 2004; p.99
10. Vaikos Chandrashekhar Dattatraya. Concepts of Hruday (Ayurved) in the sense of heart and brain. Int. J. Res. Ayur.Pharm.2013;4(1:92-95)

11. Acharya J. T., Charaka Samhita, Siddhisthana, Chapter 9, Verse 6, $1^{\text {st }}$ d, Delhi; Chaukhambha orientalia, 2004; p.717

12. Acharya J. T., Charaka Samhita, Sutrasthana, Chapter 11, Verse 38, $1^{\text {st }}$ ed, Delhi; Chaukhambha orientalia, 2004; p.75

13. Acharya J. T., Charaka Samhita, Sharirasthana, Chapter 1, Verse 29-30, $1^{\text {st }}$ d, Delhi; Chaukhambha orientalia, 2004; p. 289

14. Acharya J. T., Charaka Samhita, Sharirasthana, Chapter 1, Verse 133, $1^{\text {st }}$ d, Delhi; Chaukhambha orientalia, 2004; p.299

15. Annambhatta, Tarkasangraha, reprint ed, Mumbai; Nirnaya Sagar Press, 1876;p.22

16. Kunte A. M., Ashtanga Hrudayam, Sutrashana, Chapter 12, Verse 7, reprint 2000, Varanasi; Krushnadas academy, 2000; p.193

\section{Cite this article as:}

Neha Dattatraya Gadgil, Kalpana Dilip Sathe, Vinita Deshmukh, Akshar Kulkarni, Abhijit H. Joshi. A review on physiology of purishavega (defecation reflex). Int. J. Res. Ayurveda Pharm. 2017;8(1):1-3 http://dx.doi.org/10.7897/2277-4343.0811

Disclaimer: IJRAP is solely owned by Moksha Publishing House - A non-profit publishing house, dedicated to publish quality research, while every effort has been taken to verify the accuracy of the content published in our Journal. IJRAP cannot accept any responsibility or liability for the site content and articles published. The views expressed in articles by our contributing authors are not necessarily those of IJRAP editor or editorial board members. 